\title{
The Use of Active Compound in the Methanol Extract of Alstonia Acuminata for the Improvement of Non-Specific Immune System in Tiger Grouper (Epinephelus Fuscoguttatus)
}

\author{
J. Dangeubun \\ Student of Postgraduate, Faculty of Fishery and Marine \\ University of Brawijaya
}

Hardoko

Faculty of Fisheries and Marine Sciences

University of Brawija

\section{S. Andayani}

Faculty of Fisheries and Marine Sciences

University of Brawija

Y. Risjani

Faculty of Fisheries and Marine Sciences

University of Brawija

Received: February 28, 2013 Accepted: March 14, 2013

doi:10.5296/jbls.v4i2.3682ＵRL: http://dx.doi.org/10.5296/jbls.v4i2.3682

\begin{abstract}
Tiger grouper (Epinephelus fuscoguttatus) was very susceptible to the poor environment and therefore, weak against infection. A solution to this problem was by using immune response of
\end{abstract}




\section{Mll Macrothink}

Journal of Biology and Life Science ISSN 2157-6076 2013, Vol. 4, No. 2

fish body. The objective of research was to understand the ability Alstonia acuminata in improving immune system for the control of Vibrio harveyi disease and to acknowledge the effective dose to increase the survival rate of grouper. Parameters that were observed included macrophage, phagocytosis activity, leukocyte total, and grouper survival rate in the observation at day-1, day-3, day-5, and day-7. Result of research indicated that macrophage cells were increased at day-1 to day-5, but decreased at day-7. The dose of $200 \mathrm{ppm}$ had the highest macrophage at day-5, precisely $15.5 \times 10^{5}$ cells $/ \mathrm{mL}$, and then, it decreased at day- 7 to $15.2 \mathrm{x}$ $10^{5}$ cells $/ \mathrm{mL}$. The highest increase of phagocytosis was found at day-5 for $73.67 \%$, and observed in the dose of $200 \mathrm{ppm}$, but it decreased at day-7 for $71 \%$. The control fish had lowest means of leukocyte, precisely ranging from 24,433 cells $/ \mathrm{mL}$ to 25,283 cells $/ \mathrm{mL}$. The highest leukocyte was obtained at day-5, precisely 72,666 cells $/ \mathrm{mL}$. Result of research concluded that A. acuminata extract could increase the non-specific immune system (number of macrophage cell, phagocytosis activity, and leukocyte) against $V$. harveyi bacteria. The highest survival rate was $94.4 \%$, which was obtained from dose $200 \mathrm{ppm}$.

Keywords: Alstonia acuminate, Tiger grouper, Vibrio harveyi, Immune response, Active compound

\section{Introduction}

Tiger grouper (Epinephelus fuscoguttatus) was widely distributed in tropical and sub-tropical areas. It was the most favorite seafood with good marketability in the domestic and international markets, and therefore, it had high sale value. Market demand for this commodity was very stable and even increasing from year to year. It was not surprising to say that the cultivation work of grouper would give good prospect. However, main barrier of this grouper cultivation was its high mortality from rearing stage to harvesting stage. Main causes of high mortality in the grouper cultivation were high cannibalism and mass death due to certain disease ( Ninawe, 2006; Badrelin, et al., 2008; Karthupandi, et. Al., 2010.).

Diseases could attack fish when the water quality decreased and lead to poor health among fishes. Intensive cultivation system might cause such risks especially when the seed exceeded environmental carrying capacity. One of serious diseases in grouper cultivation was the infection from Vibrio pathogen bacteria, mainly $V$. harveyi. During peak of epidemic, fish immune was deprived, and fish was easily subjected to stress, being infected and then dead (Badrelin et al., 2008).

The medication so far involved medicines and antibiotics, such as oxytetracycline, cananycine, chloramphenicol and terramycin (Selvaraj et al., 2006; Lightner, 1996). One of these medication agents for fish disease, such as tetracycline, had been used (Jun et al, 2010) but without satisfying result. The use of chemicals was instead emerging new problems such as environmental pollution and the presence of antibiotic residue in fish tissue (Rairakhwada et al., 2007; Khachatryan, 2006; Maqsood et al., 2009). Avoiding the negative impact of antibiotics would require safer medication method, among other by increasing fish immune against disease (Selvaraj et al., 2006).

Increasing fish immune was one favorable alternative to conventional medication for disease 
alleviation, but it always involved immunostimulant. Indeed, immunostimulant represented a type of chemical, drug, stressor or activator which increased fish immune response to have direct interaction with immune system cells (Kumari and Sahoo, 2006; Wang,et al, 2009). Immunostimulant had been widely used in some fish species by embedding it into the food, by injection and/or by submersion. Some researches examined the possibility of this stimulus to increase body immune for the alleviation of more generalized diseases including those caused by virus, bacteria or dangerous organism and polution (Rao et al, 2006; Christybapita et al., 2007; Divyagnaneswari et al., 2007; Ji et at,, 2007;. Sahu et al., 2007;. Harikrishnan et al., 2009;. Pratheepa et al., 2010; Risjani et al., 2012; Maftuch et al., 2012; Andayani et al., 2006; Andayani et al., 2007).

A naturally-based immunostimulant material could be taken from a plant with environmental friendly nature but useful for $V$. harveyi alleviation, respectively Alstonia acuminata. Crude extract of Alstonia acuminata was useful for being immunostimulant active substance to increase non-specific immune system of tiger grouper in controlling $V$. harveyi

\section{Method}

2.1 The Extraction of Active Substance, and The Experiment of Adding Crude Extract A. Acuminata into Tiger Grouper and of Infecting Fish with V. Harveyi

Fresh bark of A. acuminata was taken from the research site at Southeast Maluku District. It was dried, cut into small pieces, ground into fine dust, and macerated at room temperature with methanol solvent for $3 \times 24$ hours. This extract was then partitioned with n-hexane and ethyl acetate solvents by the ratio of solvent to material of 4:1 (Harborne, 1987).

The grouper was maintained in the 40 liters batch with clean water and $150 \mathrm{ppm}$ chlorine. It was neutralized by 75 ppm chemical-grade natrium tiosulfate. Fish was acclimated for 7 days, with adjusted temperature and salinity. Fish was removed into submersion batch and given immunostimulant of $A$. acuminata crude extract at several doses, such as $0 \mathrm{ppm}$ (normal control), $50 \mathrm{ppm}, 100 \mathrm{ppm}, 150 \mathrm{ppm}$, and $200 \mathrm{ppm}$ for 1 hour (based on period length in the result of toxicity test). After submersion, fish was returned to maintenance batch and incubated for 3 days. At day-3, fish was placed again in the extract submersion batch and submerged for 1 hour. After this, the challenge test against the density of bacteria $V$. harveyi at $10^{7}$ cells $/ \mathrm{mL}$ was conducted. Observation and measurement were carried out for 7 days to acknowledge macrophage, phagocytosis, leukocyte total, plasma protein, and the number of living fish.

\subsection{Parameters to Observe}

Parameters to observe were number of macrophage (measured based on lrianto, 2005), phagocytosis, leukocyte total (based on Bijanti, 2005; Harikrisnan et at., 2010) and survival rate of grouper.

\section{Result}

\subsection{The Change of Grouper Macrophage after the Addition of Crude Extract A. Acuminata}

Macrophage change in tiger grouper after the adding of crude extract of A. acuminata was 
shown in Figure 1.

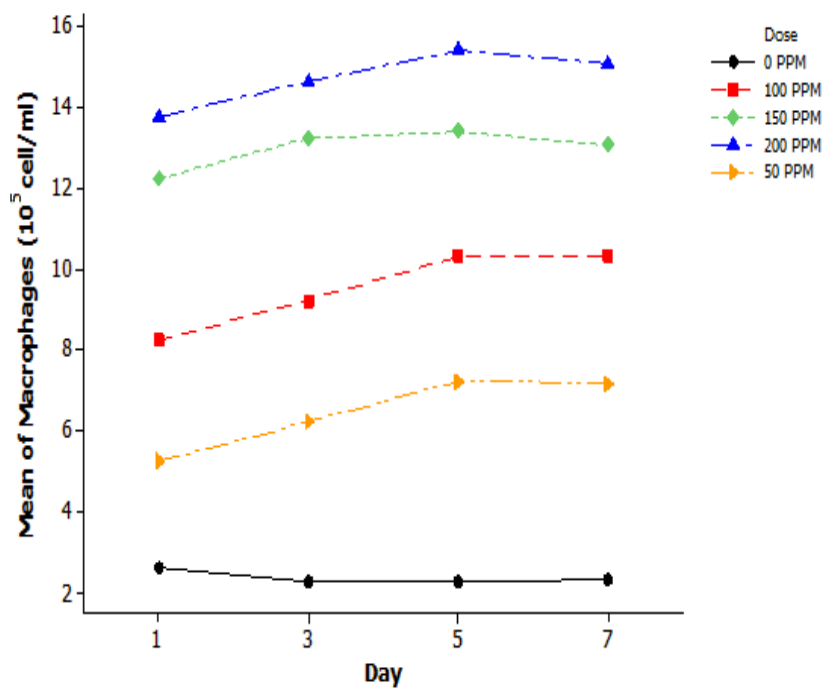

Figure 1. The change of tiger grouper macrophage based on A. acuminata crude extract doses

\subsection{Phagocytosis}

The change of phagocytosis in tiger grouper based on A. acuminata crude extract doses was indicated in Figure 2.

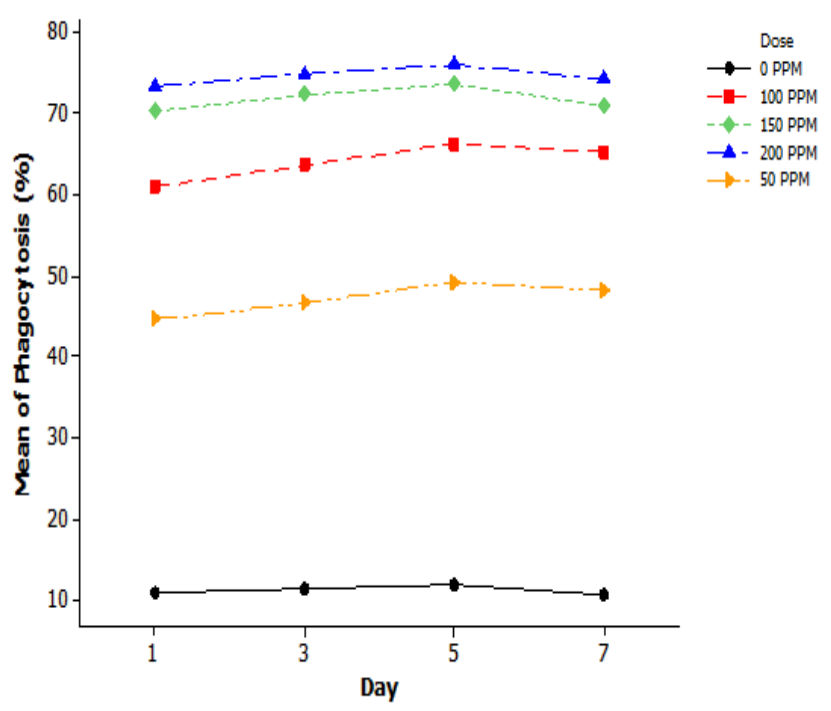

Figure 2. The change of tiger grouper phagocytosis based on A. acuminata crude extract doses

\subsection{Leukocyte Total of the Trialed Fish}

Leukocyte was a component of blood cells which functioned as non-specific defense to localize and to eliminate pathogen through phagocytosis process (Andayani, 2007). The 


\section{$\Lambda$ Macrothink}

change of leukocyte total in tiger grouper based on A. acuminata crude extract was shown in Figure 3.

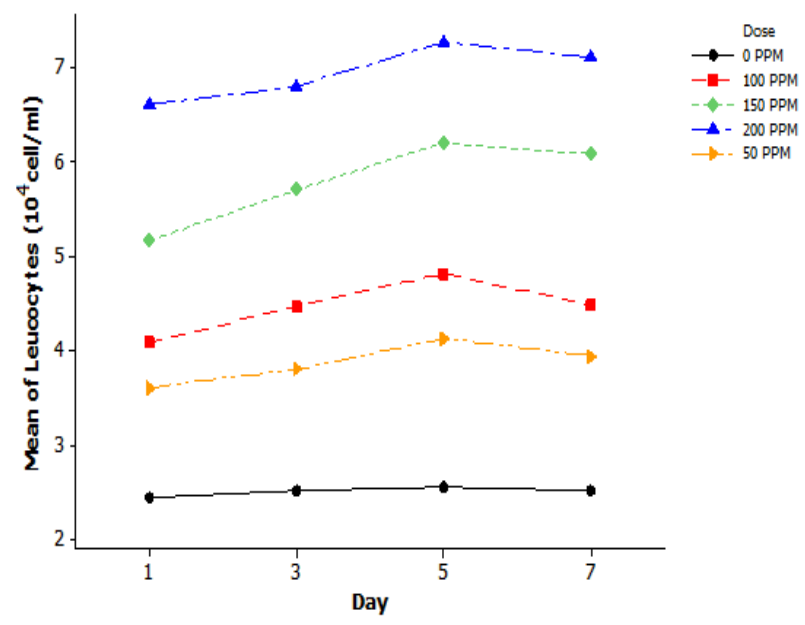

Figure 3. The change of tiger grouper leukocyte total based on A. acuminata crude extract doses

Figure 3 showed that leukocyte total was increased at day- 5 for 72,666 cells $/ \mathrm{mL}$ but decreased at day-7 to 71,100 cells $/ \mathrm{mL}$, while at $0 \mathrm{ppm}$ dose (control), leukocyte total was $24,433 \mathrm{cell} / \mathrm{s} / \mathrm{mL}$. Appropriate immunostimulant dose could increase activities of complement substance, opsonine macrophage, phagocytosis, and PMn leukocyte. It also might facilitate the elimination of incoming antigens, thus preventing the fatalism of infection. The increased leukocyte total meant the presence of humoral and cellular responses of leukocyte in dealing with the bacteria (Erlinger, 2004; Finlay et al., 2006; Magnadottir, et al., 2005).

The production of leukocyte would be delivered to the infected part of the body, and it stimulated the fish body to produce defense. At day-7, leukocyte decreased and it seemed that fish body was only sustained until day-5. It was followed by leukocyte decrease as shown by histological damage in fish body at treatment of extract doses of 50 ppm, 100 ppm and 150 ppm.

The treatment with $200 \mathrm{ppm}$ dose produced higher leukocyte total if it was compared to $0 \mathrm{ppm}$ (control), $50 \mathrm{ppm}, 100 \mathrm{ppm}$ and $150 \mathrm{ppm}$ doses. It meant that the higher concentration of $A$. acuminata crude extract that was given to tiger grouper was producing higher leukocyte total in the fish. Indeed, $200 \mathrm{ppm}$ dose was the effective dose of $A$. acuminata crude extract because it could eliminate bacteria $V$. harveyi that infected the fish. It was supported by the fact that body histology of the fish that was given 200 ppm dose was only experiencing minor damage of body organ if it was compared to 0 ppm (control), 50 ppm, 100 ppm and 150 ppm doses.

\subsection{Plasma Protein Characteristic with Electrophoresis}

Result of research indicated that protein fraction was emerging in each sample. Testing with SDS PAGE electrophoresis had produced profiles and molecular weights of the protein in each blood plasma sample. 


\section{Macrothink}

The description of protein profile of blood plasma after infection was using normal control, bacterial control and extract control, as displayed in Figure 4. The difference of protein pattern in each sample was found in the thickness rate and the number of protein ribbons. Electrophoresis count indicted that the extract concentration had more protein ribbons than the control.

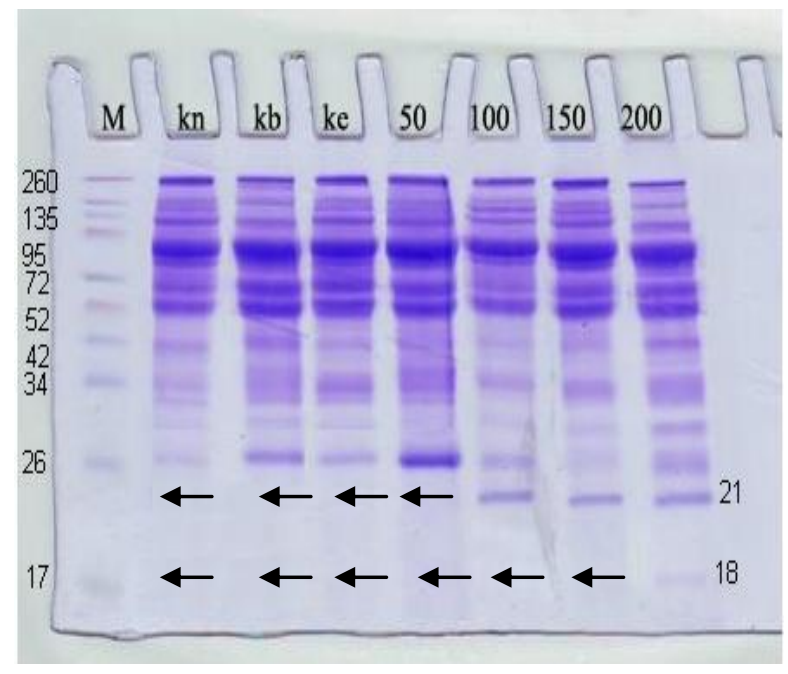

Figure 4. SDS Page over tiger grouper with A. acuminata crude extract

Notes: $\mathrm{M}=$ marker, $\mathrm{kn}=$ normal control, $\mathrm{kb}=$ bacterial control, $\mathrm{ke}=$ extract control, at 50, 100, 150 and 200 doses.

\subsection{Survival Rate of Tiger Grouper}

Survival rate was one of main parameters and success keys for aquaculture business. The providing of $A$. acuminata extract immunostimulant to tiger grouper fish could increase the body defense of the seed to control against $V$. harveyi disease, and therefore, it would improve the survival rate of tiger grouper. The survival rate of tiger grouper based on A. acuminata crude extract doses was shown in Figure 5.

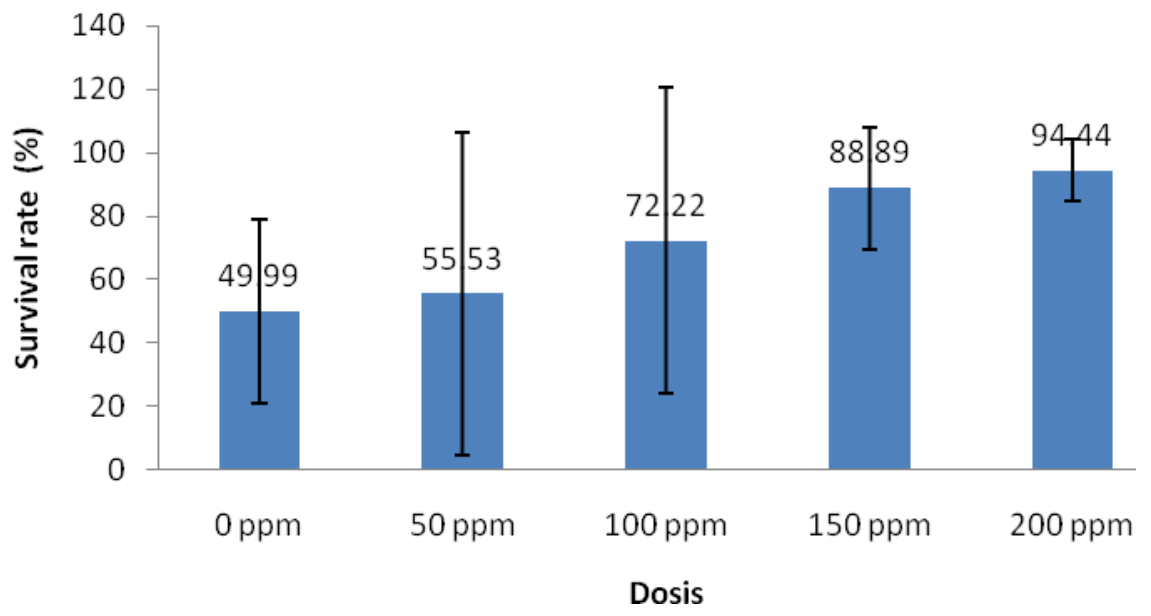


Figure 5. The survival rate of tiger grouper based on A. acuminata crude extract doses.

Tiger grouper was submerged into A. acuminata crude extract. Figure 5 showed that the highest survival rate of tiger grouper was $94 \%$ achieved at $200 \mathrm{ppm}$ concentration. The lowest survival rate was $56 \%$ reached at $50 \mathrm{ppm}$ concentration. At $0 \mathrm{ppm}$ dose (control), the survival rate was $50 \%$. Based on these findings, it was said that the effective treatment of $A$. acuminata crude extract was at $200 \mathrm{ppm}$ concentration, if it was compared to $0 \mathrm{ppm}$ (control), $50 \mathrm{ppm}, 100 \mathrm{ppm}$, and 150 ppm concentrations.

\section{Discussion}

Macrophage referred to a phagocyte cell that belonged to the precursor cells in the bone marrow. The divided premonocyte would produce monocyte, and monocyte circulated with blood to play a role as the reactor of body immunology which then had receptor to attach antibody and to destroy alien substance. Main function of macrophage in the body immune system was to swallow the particles, to subject it to the digestion by lisozom, and to deliver resultant substances for body defense. The macrophage could influence activity of immune response. It also processed and stored antigents, and sent the information to the immunologically competent nearby cells (such as lymphocyte and plasma cells). It also could be sectorial cells which released important substances such as enzymes, lisozymes, elastase, collagenase, protein and complement system, like interferon. (Sang et al., 2007; Mishra et al., 2006;. Kumar and Mukhajee, 2007).

In study the number of macrophage was increased at day-5 for $15.5 \times 10^{5}$ cells $/ \mathrm{ml}$ and decreased at day-7 to $15.2 \times 10^{5}$ cells $/ \mathrm{ml}$. The higher dose produced higher number of grouper macrophage. It proved that fish body was tolerant to the extract doses and still able to produce macrophage cell to suppress the growth of bacteria $V$. harveyi. Therefore, at day-7, the number of macrophage was decreased. This is supported by studies Risjani et al., (2012) using the extractas an ingredient immunostimulataoftory Gracillaria verucosa which showed an increase in macrophage cells are able to suppress the growth of bacteria V.harveyi.

This finding supported Anderson (1995) and Tizard (1998), which indicated that macrophage played important role in the fish body defense system against pathogen infection, and the number of macrophage increased in case of infection. It was supported by Lou et al (2012) who said that coumaric compound in the A. acuminata extract could destroy bacterial membrane cells and bind bacterial DNA such that this DNA could not express itself and thus, it was causing bacteria to death.

Fish with A. acuminata crude extract had greater non-specific defense ability if it was compared to $0 \mathrm{ppm}$ dose (control). Immunostimulant-exposed dose at $200 \mathrm{ppm}$ could stimulate immune warning of the trialed fish, and also influence the establishment of immunity response (Anderson 1995; Thompson et al., 1995; Mayer, 2008).

Macrophage as phagocyte cells could kill bacteria through 2 mechanisms: (1) One was oxidative process involving the increased use of oxygen and hexose monophosphate shunt (HMPS), the increased production of peroxide (H2O2) and some other compounds such as superoxide anion, radical hydroxyl, oxygen singlet, myeloperoxidase. All these substances 
were interacting with enzymes. The reaction produced toxic oxygen metabolite which was useful to kill bacteria; (2) other was non-oxidative process where it involved the aid of proteins such as enzymatic hydrolytic, defenses, and lisozyme, in order to increase NO production from macrophage (Galindo, 2004; Sang et al., 2007).

The activity of phagocytosis was the ingestion of alien particles, mainly bacteria, into blood cell cytoplasm (Brown, 2000). Phagocytosis activity occurred with the contact between particles and the surface of phagocytosis cells. Cellular membrane was invaginated where two arms of cellular cytoplasm were protruded from membrane-coated vacuole (phagosom). Lisozom that was nearby phagosom was then blending with phagosom and producing enzymes that manufactured phagolyzosom or secondary lisozom to facilitate the killing of bacteria or alien particles in the phagocytosis cells.

Leukocyte played important role in the fish defense system against pathogen infection (Anderson, 1995). During infection, leukocyte was delivered into the infection system to manufacture fast defense against infectious genetic (Sadikin, 2002). The presence of $A$. acuminata crude extract was definitely helping defense system of fish to challenge bacteria infection. Coumaric compound in the A. acuminata crude extract could damage bacterial membrane cells and bind bacterial DNA such that DNA was not expressed, then causing bacteria to death (Lou et al., 2012). After this, leukocyte cells were not produced anymore in greater number.

The increased leukocyte population was caused by the increased rate of activities such as the division of cells and the production of mitogenic immunostimulant. Mitogenic compounds would activate defense cells toward differentiation. It caused DNA in the lymphocyte cells to produce synthesis, thus triggering the increase of leukocyte population (Rorstad et al., 1993).

In study indicated that the phagocytosis rate increased at day-5 for $76.67 \%$ but decreased at day-7 to $74.33 \%$. Meanwhile, 0 ppm dose (control) had phagocytosis means of $11 \%$. The adding of $A$. acuminata extract influenced the increase of phagocytosis activity, where the higher dose would produce higher phagocytosis activity. Result of Dangeubun, J (2012) indicated that the isolation of $A$. acuminata methanol crude extract was containing a compound methyl 6-hydroxy-2-methoxy3-(2 oxohexy) benzoate. This compound was part of phenolic which containing $\mathrm{OH}$ cluster and interacting with bacterial protein. Macrophage cells might recognize and stimulate macrophage to activate T-lymphocyte cells. Indeed, T-lymphocyte cells produced interferon (lymphokin) and reactivated macrophage such that the ability of macrophage to phagocyte the bacteria was increased, thus increasing also phagocytosis rate.

Research about non-specific immune response was also carried out by Invadens and Dhanuskodi (2011). It used methanol extract of nigrum solanum leaf and the result showed that phagocytosis was significantly increased and non-specific response was induced to help preventing epizootic ulcerative syndrome in fish.

Above figure indicated that $200 \mathrm{ppm}$ extract had 11 protein ribbons. Two of them were missing, that was protein ribbon $21 \mathrm{kDa}$ and $18 \mathrm{kDa}$, during normal control, bacterial control, extract control, and $50 \mathrm{ppm}$ treatments. The change in the molecular weight was estimated as 
happening during the infection of the fish. It related to the presence of bacterial activity in the fish body with negative impact such as damaging certain proteins or erasing some proteins. The missing of protein ribbons was caused by degradation of protein and synthesis of protein. Both also caused the vanish of cellular-based important proteins such as anti-body enzyme or cytoskeleton matrix maker protein, whereas it accelerated destruction and elimination of cells (Andayani, 2007; Albert et al., 2002; Nayer \& Reza, 2007).

It was assumed that protein played important role in the cellular defense mechanism. It was favorably expressed after treated with A. acuminata doses. The A. acuminata dose of $200 \mathrm{ppm}$ could increase body defense and survival of tiger grouper. Andayani (2007) admitted that result of protein plasma electrophoresis had showed that protein ribbons were thickened during the infection in fish.

High survival rate of tiger grouper after treated with A. acuminata crude extract might be explained by the presence of bioactive substance in A. acuminata crude extract, precisely phenol compound with its anti-bacterial nature. Phenol compound interacted with component of bacterial cell walls such that bacterial cell was permeable and phenol was diffusing into the bacterial cell, and then, prohibiting and harming bacterial growth. Phenol could also penetrate into membrane and interact with genetic material such that the bacteria were mutating (Salosso, 2011).

\section{Conclusion}

The submersion of tiger grouper in the A. acuminata crude extract solution was able to increase non-specific immune of the fish (number of macrophage cells, phagocytosis activity, and leukocyte total) at day-5 against bacteria $V$. harveyi.

Result of SDS PAGE showed that the 200 ppm extract consisted of 11 protein ribbons. Two protein ribbons were $18 \mathrm{kDa}$ and $21 \mathrm{kDa}$, that were missed from normal control, bacterial control, extract control and $50 \mathrm{ppm}$.

Doses between $0 \mathrm{ppm}, 50 \mathrm{ppm}, 150 \mathrm{ppm}$, and $200 \mathrm{ppm}$ that were producing the highest survival rate were A. acuminata crude extract at $200 \mathrm{ppm}$ dose, with survival rate of $94.44 \%$.

\section{Reference}

Albert, B., Johnsons A., Lewis, J., Raff, M., Roberts K., \& Walter, P. (2002). Moleculer Biology of The Cell. Edisi 4. Garland Science : New York.

Andayani, S. (2007). Effect of Bioactive Alkaloids Jellyfish (Bougainvillia sp) as Immunostimulan against Bactericide Activity, Non-Specific Immune Response and Graduation (RPS) Tiger Grouper (Epinephelus fuscoguttatus). Dissertation Faculty of Agriculture. University of Brawijaya. 153 p.

Andayani, S. dan Y. Risjani. (2006). The effect of the active alkaloid compound jellyfish (Bougainvillia sp) on histological changes after the tiger grouper fish gills infected with Vibrio harveyi. J. Aquaculture Indonesia. 7(2), 85-92.

Andayani, S., Rustidja, Risjani, Y., Sukoso, \& M. Fajar. (2007). Effect of active alkaloid 
compounds jellyfish (Bougainvillia $s p$ ) in feed for tiger grouper kidney macrophages. $J$. Penel. Perik. 10(1), 102-106.

Anderson \& G. L., Rumsey. (1995). Injection or immersion delivery of selected immunostimulants to trout demonstrate enhancement of non specific defence mechanisms and protective immunity. In : M.Sharif, J.R. Arthur and R.P. Subangsihe (Eds). Diseases in Asian Acuaculture II. Proceeding of second Symposium on Diseases in Asian Aquaculture. 25-29 october 1993. FHS-AFS.p. 413-426.

Badrelin. H. Ali, G. Bluden, O. Musbah, Tanira \& Abderrahim N. (2008). Some phytochemical pharmacological and Toxicological properties of Ginger (Zingiber officinale Rolcoe); A Review of recent research science Direct. food and chemical toxicology: 46. 409-420,

Bijanti, R. (2005). Hematology Blood Collection Techniques Fish and Fish Inspection Hematology. Part of Veterinary Basic Medical Sciences. Faculty of Veterinary Medicine. Airlangga University. Surabaya.

Brown, K. M. T. (2000). Applied Fish Pharmacology. Kluwer Academic Press. London. http://dx.doi.org/10.1007/978-94-017-0761-9

Christybapita, D., Divyagnaneswari, M. \& Michael, R. D. (2007). Oral administration of Eclipta alba leaf aqueous extract enhances the non-specific immune responses and disease resistance of Oreochromis mossambicus. Fish and Shellfish Immunology, 23, 840-852. http://dx.doi.org/10.1016/j.fsi.2007.03.010

Dangeubun, J. (2012). Isolation of Pure Compounds of Land Plant Alstonia acuminate (Dissertation Research Faculty of Fisheries. UB (unpublished).

Divyagnaneswari, M., Christybapita, D. \& Michael, R. D. (2007). Enhancement of non-specific immunity and disease resistance in Oreochromis mossambicus by Solanum trilobatum leaf fractions. Fish and Shellfish Immunology, 23, 249-259. http://dx.doi.org/10.1016/j.fsi.2006.09.015

Erlinger, T. P. (2004). WBC Count and the Risk of Cancer Mortality in a National Sample of U.S. Adults: Results from the Second National Health and Nutrition Examination Survey Mortality Study. Cancer Epidemiology, Biomarkers \& Prevention 13: 1052

Finlay, B., \& McFadden G. (2006). Antiimmunology: evasion of the host immune system by $\begin{array}{llll}\text { bacterial and viral } & \text { 767-82. }\end{array}$ http://dx.doi.org/10.1016/j.cell.2006.01.034

Galindo, V. J., \& H. Hosokawa. (2004). Immunostimulants : Toward Temporary Prevention of Diseases in Marine Fish. Kochi University, Faculty of Agriculture. Laboratory of Fish Nutrition B200 Monobe, Nankoku, Kochi 783-8502 JAPAN 279-469.

Harbone, J. B. (1978). Phytochemical Methods. How to Analyze Wizard Modern Plant. Interpreting: Padmawinata, K and Soediro, I. ITB. Bandung, 189p.

Harikrishnan, R., Balasundaram, C., Dharaneedharan, S., Moon, Y. G., Kim, M. C., Kim, J. S. 
\& Heo, M. S. (2009). Effect of plant active compounds on immune response and disease resistance in Cirrhina mrigala infected with fungal fish pathogen, Aphanomyces invadans. Aquaculture Research, 40, 1170-1181. http://dx.doi.org/10.1111/j.1365-2109.2009.02213.x

Harikrishnan, R., C. Balasundaram, \& M. S., Heo. (2010). Herbal supplementation diets on hematology and innate immunity in goldfish against Aeromonas hydrophila. Fish \& Shellfish immunology, 27. 508-515. http://dx.doi.org/10.1016/j.fsi.2009.11.013

Irianto. (2005). Patologi Ikan Telostei 256 hal. Yogyakarta Gadjahmada Universitiy Press.

Invadens, P., Dhasarathan \& dhanuskodi. (2011). Evaluation of immunostimulant potential of Solanum nigrum L. Using fish, etroplus suratensis challenged with aphanomyces Invadens. International journal of pharma and bio sciences. 2, 429-438

Ji, S. C., Takaoka, O., Jeong, G. S., Lee, S. W., Ishimaru, K., Seoka, M. \& Takii, K. (2007). Dietary medicinal herbs improve growth and some non-specific immunity of red sea bream $\begin{array}{lllll}\text { Pagrus } \quad \text { major. } & \text { Fisheries } & \text { 63-69. }\end{array}$ http://dx.doi.org/10.1111/j.1444-2906.2007.01302.x

Jun, WJ., Ji HK., Dennis KG., Casiano HC. Jr., Jee EH., Sang PS., \& Se CP. (2010). Occurrence of tetracycline-resistant Aeromonas hydrophila infection in Korean Cyprinid loach (Misgumus anguillicaudatus). African Journal of Microbiology Research 4 (9), 849-855.

Khachatryan, A. R. Besser, D. D. Hancock \& D. R. Call. (2006). Use of a nonmedicated dietary supplement correlates with increased prevalence of streptomycinsulfatetracycline-resistant Escherichia coli on a dairy farm. Appl. Environ. Microbiol. 72, 4583-4588. http://dx.doi.org/10.1128/AEM.02584-05

Karuthapandi., M. B. \& Xavier Innocent. (2010). Immune responses of Tilapia mossambicus administered with rat serum vaccine for Vibrio anguillarium, Current Biotica, 4(1), 63-72.

Kumar, \& S. C. Mukherjee. (2007). Haemato-immunological responses to dietary yeast RNA, $\omega$-3 fatty acid and $\beta$-carotene in catla catla juveniles, Fish and Shellfish Immnol, 23, 917-927.

Kumari, J. \& P. K., Sahoo. (2006). Dietary [beta]-1,3 glucan potentiates innate immunity and disease resistance of Asian catfish, Clarias batrachus (L.). J. Fish Dis. 29, 95-101. http://dx.doi.org/10.1111/j.1365-2761.2006.00691.x

Lightner, D. V. (1996). A. Handbook of shrimp pathology and diagnostic procedures for diaseases of culture penaeid shrimp. Word Aquaculture society. Lousiana, 157 p.

Lou, Z, H. Wang. S. Rao. J. Sun, C Ma. J. Li. (2012). P-Coumaric acid kills bacteria through dual damage mechanisms. Food control. 25, 550-554. http://dx.doi.org/10.1016/j.foodcont.2011.11.022

Maftuch, Mahfud, H. Toban, \& Y. Risjani. (2012). Administration of marine algae (Gracillaria verucosa) immunostimulan enhances some innate immune parameters in black tiger shrimp (Peneaus monodon Fabricus) against Vibrio harveyi infection. Journal of Applied Sciences Research, 8(2), 1052-1058. 
Magnadottir, B., Lange S, Gudmundsdottir S, Bogwald J, \& Dalmo, R. A. (2005). Ontogeny of humoral immune parameters in fish. Fish and Shellfish Immunology 19, 429-439. http://dx.doi.org/10.1016/j.fsi.2005.03.010

Mayer, A., \& Gustafson, K. (2008). Antitumour and Cytotoxic Compounds. European Journal Of Cancer, 44, 2357-2387. http://dx.doi.org/10.1016/j.ejca.2008.07.001

Maqsood, S., M. H. Samoon, \& P. Singh. (2009). Immunomodulatory and Growth Promoting Effect of Dietary Levamisole in Cyprinus carpio Fingerlings Against the Challenge of Aeromonas hydrophila. Turkish Journal of Fisheries and Aquatic Sciences, 9, 111-120.

Mishra. S. N. P., Sahu, A. K., Pal, B. Xavier \& S. C., Mukherjee. (2006). Pre and post challenge immuno-haematological changes in L. rohita juveniles fed gelatinized and non gelatinized carbohydrate with n-3 PUFA, Fish Shellfish Immunol, 21, 346-356. http://dx.doi.org/10.1016/j.fsi.2005.12.010

Nayer, Mohammadkhani, \& dan Reza Heidari. (2007). "Effects of Drought Stress on Soluble Proteins in two Maize Varieties". Turk J Biol. 32, 23-30.

Ninawe, A. S. (2006). DNA vaccination and prophylactic measures in aquatic health management, Aquaculture. Asia Mag. 21-23.

Pratheepa, V., Ramesh S. \& Sukumaran, N. (2010). Immunomodulatory effect of Aegle marmelos leaf extract on freshwater fish Cyprinus carpio infected by bacterial pathogen Aeromonas hydrophila. Pharmaceutical Biology, 48, 1224-1239. http://dx.doi.org/10.3109/13880201003713598

Rairakhwada., Dina, A. K., Pal, Z. P. Bhathena, N. P., Sahu, A. Jha, \& S. C. Mukherjee. (2007). Dietary microbial levan enhances cellular non-specific immunity and survival of common carp (Cyprinus carpio). Fish \& Shelfish Immunology, 22, 477-486. http://dx.doi.org/10.1016/j.fsi.2006.06.005

Rao, Y. V., Das, B. K., Jyotyrmayee P., \& Chakrabarti, R. (2006). Effect of Achyranthes aspera on the immunity and survival of Labeo rohita infected with Aeromonas hydrophila. Fish and Shellfish Immunology, 20, 263-273. http://dx.doi.org/10.1016/j.fsi.2005.04.006

Risjani, Y. S. Musliha, A. Hermawati, J. Couteau, \& C. Minier. (2012). Assessment of fish health status in the Brantas river, Indonesia. Comparative Biochemistry and Physiology Part A: Molecular \& Integrative Physiology. Volume 163 supplement . Page S42. http://dx.doi.org/10.1016/j.cbpa.2012.05.125

Rorstad, G., P. M. Asjord \& B. Robertsen. (1993). Adjuvant effect of yeast glucan in vaccines against furunculosis in Atlantic salmon (Salmo salar L). Journal Fish and Shellfish Immunology, 3, 179-190. http://dx.doi.org/10.1006/fsim.1993.1018

Sadikin, H. M., (2002). Blood Biochemistry. Publisher Widya Medika.

Sahu, S., Das, B. K., Pradhan, J., Mohapatra, B. C., Mishra B. K. \& Sarangi, A. (2007). Effect of Magnifera indica kernel as a feed additive on immunity and resistance to Aeromonas 


\section{Macrothink}

Journal of Biology and Life Science ISSN 2157-6076 2013, Vol. 4, No. 2

hydrophila in Labeo rohita fingerlings. J. Fish and Shellfish Immunology, 23, 109-118. http://dx.doi.org/10.1016/j.fsi.2006.09.009

Sang, H. C., Kwan, H. P., Taek, J. Y., Jong, B. K., Yong, S. J, \& Chung, H. C. (2007). Dietary Korean mistletoe enhances cellular non-specific immune responses and survival of Japanese eel (Anguilla japonica). Fish \& Shellfish Immunology. 67-73p

Salloso,Y. (2011). Bioactive Compounds brown macroalgae Padina australis as the Natural Antibacterial Control Vibrio alginolyticus on Cultured Rat Grouper (Cromileptes altivelis). Dissertation Faculty of Fisheries and Marine Sciences University of Brawijaya. It 185.

Selvaraj, V., K. Sampath, \& V. Sekar. (2006). Adjuvant and immunostimulatory effects of b-glucan administration in combination with lipopolysaccharide enhances survival and some immune parameters in carp challenged with Aeromonas hydrophila. Veterinary Immunology and Immunopathology, 114, 15-24. http://dx.doi.org/10.1016/j.vetimm.2006.06.011

Thompson, K. D., A. Cashos \& V.Inglis. (1995). Immunomodulating effect of glucans and oxytetracycline in Rainbow trout (Onchorhynchus mykis) on serum lysozyme and protection. In : M. Sharif,J.R. Arthur and R.P. Subangsihe (Eds). Diseases in Asian `Aquaculture II. Proceeding of Second Symposium on Diseases in Asian Aquaculture. 25-29 $9^{\text {th }}$ October 1993. FHS-AFS.p. 433-440.

Tizard, I. (1998). An Introduction to Veterinary Immunology. Terjemahan: Mazduki dan S. Hardjosworo. Pengantar Immunology Veteriner. Universitas Airlangga. Surabaya. 197 pp.

Wang, T. Yongxin, S., Liji J., Yongping X., Li W., Tongjun R., \& Kailai, W. (2009). Enhancement of non-specific immune response in sea cucumber (Apostichopus japonicus) by Astragalus membranaceus and its polysaccharides. Journal Fish and Immunology, 27(6), 757-762. http://dx.doi.org/10.1016/j.fsi.2009.09.002

\section{Copyright Disclaimer}

Copyright reserved by the author(s).

This article is an open-access article distributed under the terms and conditions of the Creative Commons Attribution license (http://creativecommons.org/licenses/by/3.0/). 